\title{
TEN POINTS OF SUSTAINABLE BANKING
}

András Becsei - Péter Csányi - Attila Bógyi -

Ildikó Kajtor-Wieland - Levente Kovács ${ }^{1}$

\begin{abstract}
Over the past decades, it has become more and more obvious that the banking system has contributed to the implementation of sustainability goals in a more committed manner in terms of both its institutional operation and in the course of the fulfilment of its tasks. In domestic context, there have been initiatives; however, it may be necessary to lay down principles pointing towards sustainable banking, which can strengthen the sustainability of the banking sector at systemic level, as well as the contribution of banks to the achievement of sustainability goals. On the one hand, the study introduces successful legislative initiatives related to the 22-point digitalisation proposal package of the Hungarian Banking Association, on the other hand, it points out that long-term sustainability and competitiveness of banking operation can be achieved by the optimisation of current processes as well as by effective and competitive data management through green financing activity. The definition of more exact steps along the aforementioned goals can lead to spectacular advancement in the fields of strengthening the sustainability and the sustainability effect of the Hungarian banking system.
\end{abstract}

JEL codes: G21, G28, Q56

Keywords: sustainability, banking system, green financing, digitalisation

1 András Becsei, Vice President of the Hungarian Banking Association; CEO of OTP Mortgage Bank. E-mail: andras.becsei@otpbank.hu.

Péter Csányi, President of the Digitalisation Working Group of the Hungarian Banking Association; Deputy CEO of OTP Bank. E-mail: csanyi.peter@otpbank.hu.

Attila Bógyi, President of the Legal Subcommittee of the Mortgage Bank Working Group of the Hungarian Banking Association. E-mail: bogyi.attila@otpbank.hu.

Ildikó Kajtor-Wieland, Chief Legal Officer of the Hungarian Banking Association. E-mail: kajtor-wieland.ildiko@bankszovetseg.hu.

Levente Kovács, Secretary General of the Hungarian Banking Association; professor of the University of Miskolc.

E-mail: kovacs.levente@bankszovetseg.hu. 


\section{THE BALANCE OF THE 22 POINTS OF DIGITALISATION - WELL-SCHEDULED PROPOSALS AT THE RIGHT TIME}

Looking back to the year 2020 in a few years' time, we will probably remember this period as one of the milestones of financial digitalisation as well as the period of extremes difficulties caused by the pandemic. The emergency situation transformed the world we had been used to within seconds, questioned yesterday's truths and broke previously unquestionable taboos. Education, everyday work, our relationships with our family members and friends, and, last but not least, our banking habits changed. The IT developments brought about by the Hungarian banks play a key role in enabling our clients to manage their finances with the unusual efficiency even during the pandemic.

The emergency situation made it obvious that the clients' demand for the use of digital banking services was growing. The banks were prepared to satisfy their needs. Over the past more than one year, a forced educational process has taken place: even those clients who did not use digital banking in the past have started using these solutions. Based on back testing conducted so far, digital development does not seem to be temporary. As we see, the majority of those clients who started using these solutions enabling safe and flexible banking are still using them after the lifting of the restrictions, as well. The existence of the trend realised by the banks is also proven by the 2021 Payment System Report of the National Bank of Hungary ${ }^{2}$, emphasising than in 2020, the rate of card transactions as well as the total annual value of purchases by bank cards grew faster than in previous years.

During the emergency situation, legislative bodies expressly requested the sector to make proposals to support digital banking. Fortunately proposal on digitalisation were already ready, they just had to be updated, based on the experience gained in the first period of the pandemic.

In the summer of 2019, members of the Hungarian Banking Association started collecting digitalisation proposals of the sector to launch a development process that could be instantly felt by clients, with the support of the legislator. Of course, there had been made proposals related to digitalisation in the banking sector, but they typically focused on the solution of a well-defined problem or current development, therefore they were less likely to result in digital breakthrough. When preparing such proposals, initiatives enabling the end-to-end digitalisation of client processes were prioritised. We believe that the elements of the 22-point digitalisation proposal package (Becsei at al., 2019) could make banking more secure,

2 NBH (2021): Fizetési rendszer jelentés (Payment System Report), https://www.mnb.hu/ kiadvanyok/jelentesek/fizetesi-rendszer-jelentes. 
client-friendly, effective and, last but not least, greener. The proposals were divided into the following four major topics and around a general principle.

First, we collected proposals aimed at lifting legal barriers. The banks expressed that immediate advancement could be achieved in several areas by lifting or easing legal restrictions. For example, such an area was Section 13 (2) of Act CLXII of 2009 on Consumer Credit that stipulated that mortgage contracts shall not be concluded electronically ${ }^{3}$, and, in the case of the value assessment of real property, time-consuming and costly on-site assessment shall be conducted, even if a city apartment, the market value of which can be determined risk-free based on the available transaction data, was the subject of the value assessment. It is favourable that the provision banning the conclusion of e-contracts has been removed from Act CLXII of 2009 on Consumer Credit since then, as we will detail it later in our study, valuation based on statistics could become a more widely used solution in the future.

The following proposals are about the integration of already existing innovative solutions into banking processes. In this part of our study, we examined the E-Administration Act ${ }^{4}$ and the digital public service framework of the government specified in the aforementioned Act, several elements of which are suitable for being applied in banking processes. It is important that the emergency situation showed that people are open to digital public administration. Based on data from July $2021^{5}$, there is appropriately large clientele for digital public administration, as the number of citizens with Client Portal (Ügyfélkapu) registration exceeded 4.7 million. From here, it would be only one step the integration of the identification-based document authentication (AVDH), which is simply used as e-signature by many, into banking processes, or the substitution of queuing in post offices by allowing banks to send messages to the storage space of clients accessible through the Client Portal, similarly to the users of the administrative portal. In our view, if the aforementioned directions of development were realised, the quality and speed of client service could be improved, contributing to paper-free operation and strengthening the sustainability of the banking sector.

3 In accordance with Section 13 (2) of Act CLXII of 2009, effective until 25 December 2020, "The contracts specified in Subsection (1) shall not be electronically concluded in accordance with Section 8 (2), however, it shall not prevent the Parties from resorting to the electronic solution to fulfil their obligation to provide information, certify the fulfilment of such obligation and the provision of the draft of the contract if the required conditions exist." Act CCXXII of 2015 on the General Rules of Electronic Administration and Trust Services.

5 https://regi.ugyintezes.magyarorszag.hu/dokumentumok/mohustat.xls. 
In addition, the legislator has taken significant steps recently to regulate the technology-neutral conclusion of e-contracts Section 46 of Act XCIX of 2021 on the Temporary Rules in Connection with the Emergency Situation ensures flexible regulatory environment for the use of innovative e-contract conclusion solutions related to financial services until 31 December 2022. By incorporating appropriate guarantees, the regulation adopted during the emergency situation ensures that legal statements made by clients through the electronic system qualify as private document providing full evidence. We recommend that the current temporary measures become part of the legal system in the long run, thus ensuring the maintenance of Hungary's regulatory competitive edge. It would be practical to examine how the e-contract conclusion solutions mentioned above could be applied in the case of financial lease contracts related to mortgage loans and real property.

The third group of proposals aims to connect digital islands and achieve efficient data management. Over the past few years, several authorities have digitalised their administrative processes, however, these digital administrative points are still separate, and transition between databases still requires human interface, i.e. the involvement of the clients themselves. Digital islands have been born in the sea of paper-based administration; however, they are mainly connected by clients. Documents issued at the end of digital processes are handed around among administration points.

We identified further possibilities for development in the areas of the flow of digitalised data and automated interconnection. In Estonia, in the framework of the e-Estonia Project, one of the most important principles is the principle of "onetime data entry", in accordance with which, in the course of a new administrative process, clients (citizens) do not have to provide the personal data which have already been provided and recorded in any of the databases of the state again. As we see, such data are available even in our country, and, by connecting databases more efficiently, the principle of one-time data entry could be met. This proposal is related to the issue of the automatic update of personal data, as well. It would be practical to notify the institutions of changes in data, as currently still clients are responsible for reporting any changes in their data in person. The latter initiative could be realised soon, as the 2021 autumn legislative programme of the Parliament ${ }^{6}$ includes a package of bills on "Data Change Management Service", the purpose of which is to decrease the administrative burden related to everyday administration, by sending verified electronic notifications of any changes in the

6 https://www.parlament.hu/documents/10181/721095/Tvalk_program_2021_\%C5\%91sz. $\mathrm{pdf} / 563 \mathrm{fb} 9 \mathrm{ec}-2 \mathrm{~b}_{3} \mathrm{~d}-833 \mathrm{a}-5383$-dcb951c29645?t=1623823967495. 
data of natural persons stored in state registers to the service providers who are in a contractual relationship with natural persons in the future.

The fourth major element of the package included proposals aimed at slowing down the rate of growth of cash use. Based on the statistics of the National Bank of Hungary of July 2021, the amount of cash held by retail clients increased by $14 \%$, to nearly HUF 7500 billion, during the emergency situation. The cost of such cash volume is estimated 7 to be HUF $400-500$ billion on the level of the entire society; therefore each Hungarian citizen incurs an indirect cost of HUF 40000-50000 due to this adverse phenomenon. It is our common interest to continue slowing down the rate of growth of the cash volume.

In addition to the above, another important principle can be found among the proposals: the implementation of the "same activity - same regulation" principle, so that digital banking services could spread as fast as possible and in the most competitive manner. Regarding the success of the digitalisation of banking, the regulatory and supervisory environment is of critical importance. If the regulation of FinTech/BigBech companies is less strict than that of financial institutions, the process can be implemented only under unequal conditions of competition and with higher risks on the client side. Unfortunately, in 2020, WireCard, a FinTech company belonging to the companies of the DAX index, went bankrupt, as it was not able to account for EUR 1.9 billion, which drew attention again to the necessity of the appropriate regulation of the FinTech sector. The analysis ordered by the European Parliament in search for regulatory lessons ${ }^{8}$ also pointed out that regulation which was similar to that in the banking sector was needed. Three of their six proposals should be dealt with separately, as well: According to the first proposal: "Regulatory arbitrage should not be allowed", i.e. the regulation of identical activities should be the same. In accordance with the third proposal, the supervision of companies and activities should be appropriately combined. The supervision of a large number of complicated activities was inadequate in the case of Wirecard, while pursuant to point 6 , there is no need for a new supervisory body, but the appropriate competent supervisory authorities should be coordinated instead.

7 NBH (2012): Jelentés a fizetési rendszerről (Report on the Payment System, https://www.mnb.hu/ letoltes/jelentes-a-fizetesi-rendszererol-2012.pdf

8 Giorgio Barba Navaretti - Giacomo Calzolari - Alberto Franco Pozzolo (2020): What are the wider supervisory implications of the Wirecard case? https://www.europarl.europa.eu/ RegData/etudes/STUD/2020/651384/IPOL_STU(2020)651384_EN.pdf. 
Experts started consultations with the legislator on the proposals already at the beginning of 2020 . The representatives of the ministries concerned and those of the central bank are committed to the digitalisation of banking. Many of the proposals were partly or fully implemented. In November 2020, the Ministry of Finance announced the following six measures in terms of digitalisation.

1. In the case of online cash registers, the provision of electronic payment solution became compulsory. Pursuant to Section 5/F of Act CLXIV of 2005 on Trade, every retailer who operates an online cash register shall provide an electronic payment solution to its customers as of 1 January 2021. The 4000o60000 retailers who have only provided a cash payment method so far can basically choose from two solutions: they can comply with the aforementioned obligation by either accepting a bank card, or receiving instant money transfers.

2. In accordance with point q) of Section 7 (3) of Act CCXXXVII of 2013 on

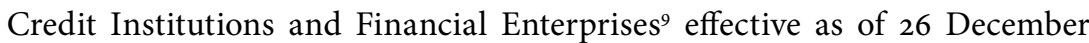
2020, the scope of commercial activities carried out by financial institutions was expanded /q) the financial institution shall be entitled to provide its clients with electronic procedures and devices which facilitate the use of the commercial services provided by the financial institution/. In the course of consultations, this point was simplified as a "digital framework agreement". In our opinion, it may create new opportunities in the relationship between clients and banks.

In this way, a flexible digital service platform can be created between banks and clients, facilitating paper-free administration at several points.

- Secure communication: this application can serve as a secure channel of communication between clients and financial institutions. It can be suitable for making some statements.

- Client identification: the platform can enable secure, real- and non-real time client identification. After successful identification, the platform can also enable access to financial products for clients.

- Product order: it is a secure platform to place product orders.

- Access to documents: it was a problem for financial institutions to make contractual documents, notifications, etc. accessible to their clients on a secure online platform in the future, as well, after the termination of contractual relationships (e.g. the termination of a payment account framework agreement, final repayment of a consumer loan). The reason for this

9 Act CCXXXVII of 2013 on Credit Institutions and Financial Enterprises. 
was that the online and mobile banking applications can be provided to clients only in the framework of in a related legal relationship (e.g. as part of a cash flow framework contract), as such application were not specified as independent services in Act CCXXXVII of 2013 on Credit Institutions and Financial Enterprises. The new platform remedies this deficiency.

3. The digitalisation of land registry procedures may accelerate bank landing processes. The most important provisions of Act C of 2021 on Land Registry shall enter into force in February 2023. A major innovation of the new law is the introduction of the automatic decision-making procedure, which can contribute to the further acceleration of banking administration and loan disbursement by reducing the lead time and human resource need of the procedures, thus decreasing the administrative burden on public administration. On the other hand, regarding the banking sector, in addition to the aforementioned advantages, the following change may result in cost increase: contrary to the effective land registry law ${ }^{10}$, authorised bank employees shall not be entitled to act as signatory parties at the time of the registration and cancellation of mortgage. The new law prescribes the collaboration of an attorney, a bar association legal counsel or a notary public instead.

At the same time, automation allows the reduction of land registry fees, as well. It would be practical to reduce the administrative service fees of land registration procedures in the fees regulation that is being prepared for the new land registry law. As a result, the advantages of digitalisation could be felt by client not only in faster procedures, but also in lower fees.

4. The amendment of Decree 25/1997 (VIII. 1.) of the Minister of Finance on the methodological principles for determining the mortgage lending value of property not qualifying as arable land allowed the wider use of statisticsbased property valuation. Based on the amendment, in the case of apartments which meet certain criteria and have a large number of transactions, the valuation can be conducted on a statistical basis instead of on-site valuation. As a result, the number of costlier on-site real property value assessment may decrease. This point should not be considered as loss of income, but rather as the rationalisation of processes. Consequently, the number of costlier on-site real property value assessment may decrease, and clients will be able to get accurate information about the expected market value of the selected real

10 Section 32 (5) of Act CXLI of 1997 on Land Registry: "Registration of a mortgage filed or terminated may also be performed on the basis of a private document signed by the representative credit institution by indicating its name in a regular and obviously identifiable manner. [...]" 
property in the first moment of borrowing, as well as about the amount of loan that can be taken out in the specific case.

5. In the case of family allowances, notarial participation became simpler and cheaper. The amendment of Decree 22/2018 (VIII. 23.) of the Ministry of Justice on Notarial Fees was published on 31 December 2020, introducing a uniform unilateral commitment model in the case of family allowances as of 1 of February 2021. The duties of notaries have become simpler, as the entire content of unilateral commitment statements prescribed by the law is to be prepared by banks. As a result of the amendment, to compensate for the decrease in notarial burden, the costs incurred by the clients were reduced by the same rate.

6. The amendment of the decree supporting transition to digital document management enabled that, in the case of transaction worth less than HUF 300,000 and after a limitation period of 5 years, it is enough to keep the copies of paper-based documents instead of the actual documents. Moreover, in 2020, Section 58 of Act CXXXIX of 2013 on the National Bank of Hungary ${ }^{11}$ was also amended. Therefore, now, it is permitted to use copies of electronic documents in supervisory control procedures, as well.

\section{THE APPEARANCE OF SUSTAINABILITY ASPECTS IN BANKING}

Climate change and several ecological effects have become more and more worrying over the past few years. The resulting natural processes have been increasingly apparent. Mankind has started realising and seriously appreciating the importance of eco-conscious action on the level of international organisation as well as on that of the individual. The pandemic proved the importance of sustainability and "green thinking", the necessity of facing the risks arising from the contact point and interaction between nature and human civilisation. At the same time, due to the acceleration of possibilities provided by digitalisation, the frameworks of economic operation have changed to some extent, and generally more ecofriendly operational and service forms with a different effect on the environment became widespread along workflows which used to be less recognised in the past. The powerful but incomplete spread of the environmental approach was due to the fact that the operation of the world's natural and economic processes ignoring environmental principles causes irreversible damages which severely affect the

11 Act CXXXIX of 2013 on the National Bank of Hungary. 
individual, larger communities, businesses and even entire industries already in the present and not only in the distant future.

Over the past few years, the conscious reduction of the ecological footprint has become an international trend in its own complexity, with underlying responsible and substantial values, as well as socio-economic interests. In line with this trend, there are more and more conscious consumers in everyday life. When shopping, they are expressly looking for products and/or services with smaller ecological footprint and trying to optimise their consumption regarding the protection of the environment. A large number of consumers can influence the success or failure of companies, and these people are also constituents. Therefore, the economy and the political system are taking them increasingly into account. Based on the above, it is clear that ecological effects and risks, as well as the related measures, are covering more and more areas, well beyond immediate environmental issues and projecting the need for long-term planning permeating our life and affecting all sectors, with the common objective to conserve the world we know in the long run.

Banking system can also contribute significantly to such processes and set an example in the area of sustainability. First, the rest of the study seeks to describe the role of the banking system in sustainability in the framework of a short review of professional literature, and then some EU-level initiatives are introduced. The backbone of thisstudy consists of proposals related to domestic sustainable banking, which could be key to intensifying measures towards sustainability.

\subsection{The role of the banking system in sustainability}

Several authors point out that the banking sector plays an important role in promoting sustainability and sustainable growth due to its mediatory role (authors to be highlighted: Yip and Bocken, 2018). The provision of financial resources required by green projects and the management of sustainable responsible investment funds (Sustainable Responsible Investment, SRI) help the funding of sustainable development goals (Sustainable Development Goals, SDG). Over the past two decades, several external shocks have shaped the business model of banks. Out of these shocks, it is worth highlighting the crisis of the financial world and the real economy in 2008, the fourth industrial revolution and the pandemic caused by the new COVID-19. The aforementioned effects clearly accelerated the digitalisation of banking services and operations (Forcadell et al., 2020), which contributed to the reduction of the ecological footprint of the sector in itself. To illustrate this, we could mention reduced paper use and a significant drop of travelling. (For example: Merely 200 sheets of generally used printer paper weigh 
$1 \mathrm{~kg}$. Irrespective of the energy consumption of printers, this volume results in the emission of $1.1 \mathrm{~kg}$ of $\mathrm{CO}_{2}$. Moreover, in the course of papermaking, half a dozen materials exploited from nature are used, ranging from wood to sulphur. In addition, during the breakdown of paper, not to mention paper burning, methane, a material harmful to the atmosphere, is released. (NBH, 2021) Of course, such steps towards the development of services and operation have their own history. At the same time, based on the chronological order of external shocks, it is not surprising that the volume of professional literature on sustainable banking has shown spectacular growth since the turn of the millennium. This fact was highlighted mainly by Aracil et al. (2021) in the journal Financial Research Letters. In their work, they examine 676 studies which were registered into the database of Web of Science (WoS) between 1995 and 2019. In their comprehensive perspective, the authors identify nine clusters or thematic areas, which are related to three narrower fields: ethical foundation, sustainable products and business cases. Based on their analysis they point out that there is gradual convergence between the instrumental and ethical approaches to sustainable bank assets. This convergence throws light on two issues: the role of the vivid social communication of banks in promoting sustainability and the spread of a business and public interest, which is becoming a business principle, based on which banks are trying to follow a sustainable business strategy.

However, it is important to clarify what we mean by sustainable banking. According to Yip and Bocken (2018), sustainable banking refers to the provision of financial products and services which were developed to satisfy the needs of users while protecting the environment and generating profit. In professional literature, the subareas belonging to sustainable banking include the social responsibility of banks, the issue of ethical banks or eco-banking and green banking (Birindelli et al., 2015; Bouma et al., 2017 inter alia). Concerning this topic, we would like to note that in domestic professional literature the discussion of the question is not detailed enough. At the same time, the deepening cooperation between the financial sector and universities, as well as the reviewing activity carried out by important consultancy firms are promising. Domestic (e.g. the green frameworks of domestic financial institutions and the green recommendation of the BSE and the NBH) and international professional initiatives (e.g. green and sustainability principles and handbooks published by the International Capital Market Association ${ }^{12}$ ) constitute an excellent basis for ending deficit and creating scientific overviews. It is obvious that attention is paid to the role and diverse activities of the financial mediatory system in this respect, as well, because the

12 ICMA Sustainable Finance, https://www.icmagroup.org/sustainable-finance/. 
funding instruments of banks constitute active, essential and supportive conditions of processes, from energy-saving private development of retail clients to the most significant green investments. Banking operation also provides the technology for the implementation of controlled state aids.

\subsection{The green swan: the financial risk of unsustainability}

At this point, it is appropriate to ask the following question: To what extent does climate change affect the two-tier banking sector? Is it an action of social responsibility or will it significantly affect the core activity of the banking sector, as well? According to Christine Lagarde, the president of the European Central Bank, without further interventions managing climate change, the probability of default of the loan portfolios of the most affected $10 \%$ of the banks will have increased by $30 \%$ by $2050^{13}$. Despite the estimate quoted above, experts emphasise the difficult applicability of the conventional risk analysis methodology. According to the BIS study entitled Green Swan ${ }^{14}$, models based on past data and calculating with previous trends are not suitable for assessing the complex effect of climate change. When the effects are clearly defined and the change has passed the irreversible points, it will be too late. The name of the study (Green Swan) is very suggestive, as well. The original term "black swan" has three features: the events (i) are unexpected and rare, therefore they are beyond normal expectations, (ii) they are extensive and extreme and (iii) can be subsequently explained. A "black swan" event may be a terror attack, a technological breakthrough or a natural disaster. Climate change, as an environmental black swan is characterised by the aforementioned points, however, there are three distinctive differences compared to the traditional definition. Firstly, although the effects of climate change are full of uncertainty, unfortunately, it seems to be sure that significant risks arise from the change. Secondly, its effects go beyond that of the financial crisis, as they also affect the physical conditions of people. Thirdly, the effects of climate change are much more complex: they make up a complicated network of environmental, social, geopolitical and financial elements.

According to the study, climate change affects financial and price stability in two ways: on the one hand, due to physical risks caused by the weather, on the other

13 Christine Lagarde (2021): Climate change and central banks - analysing, advising and acting. Speech by Ms Christine Lagarde, President of the European Central Bank, at the International Climate Change Conference, Venice, 11 July 2021. https://www.bis.org/review/r210712b.htm.

14 Patrick Bolton - Morgan Despres - Luiz Awazu Pereira Da Silva - Frédéric Samama Romain Svartzman (2020): The green swan - Central banking and financial stability in the age of climate change. January 2020, https://www.bis.org/publ/othp31.pdf. 
hand, due to "transition risks" arising from climate change. Examples for the former include extreme storms, floods and heatwaves due to changing weather conditions or the financial and economic loss caused by the rise in the water level of oceans. The number of natural disasters is increasing, $70 \%$ of the damages are uninsured. Such uninsured losses may lead to the insolvency of households, companies or even states. The remaining 30\% of the damages have a negative effect on the operation of insurance and reinsurance companies. The second-mentioned transition risks arise from the uncertainties related to more eco-conscious operation: currently, the effect of legislative amendments and technological innovations on existing industries (e.g. automobile industry, mining) is hard to predict. Regarding the risks listed above, financial risk appears sooner, however, difficulties in supply owing to adverse weather conditions might even generate inflation.

\subsection{International initiatives towards sustainable banking}

In the area of finances, several strategic-level international initiatives have appeared over the past few years, enabling the development of a coordinated, global, sector-level action instead of individual steps. The regulation is increasingly promoting the use of incentives, defining a new direction in which all participants can play an active role predictably to achieve a common goal that is important for the whole society.

For the period 2019-2024, the European Commission approved a so-called Green Deal (EU Green Deal) in order to turn the European Union into a modern, competitive economy that will be exploiting resources effectively in the future and will have become climate-neutral by 2050 . In order to achieve this goal, economic and social changes are necessary everywhere in Europe. Such changes have to take place in a cost-efficient, fair and socially-balanced manner. On the road towards climate neutrality, the Commission defined several policies and initiated several legislative measures affecting the field of finances, as well ${ }^{15}$. Supporting the Green Deal, the Commission adopted a package of measures (Sustainable Finance) ${ }^{16}$ in the area of finances in order to promote the flow of financial resources towards sustainable activities. This package can have its influence from different directions, through consultations, recommendations and EU legislation, driving the

15 EC (2021): A European Great Deal. https://ec.europa.eu/info/strategy/priorities-2019-2024/ european-green-deal_en

16 EC (2021): Sustainable Finance. https://ec.europa.eu/info/business-economy-euro/banking-andfinance/sustainable-finance_en 
sustainable and green aspects of finances into a channel that is in harmony with the strategy, instead of into individual action.

\section{SUGGESTIONS ABOUT SUSTAINABLE BANKING IN HUNGARY}

The Hungarian Banking Association - as the representative of the financial sector - coordinates the green consciousness and commitment of market participants, transforms them into a joint opinion and supports the achievements of their goals with the available means. Within the framework of this activity, having regard to the challenges the financial sector faces, its proactive social responsibility and the role of the financial mediatory system in the Hungarian economy, the Hungarian Banking Association drafted a package of proposals, which, together with the seven chapters of the Green Recommendation of the National Bank of Hungary ${ }^{17}$, contributes to sustainable banking and banking that serves sustainability in Hungary, paying particular attention to its affordability and feasibility. It is important to point out that, in our view, sustainability principally depends on the optimisation of banking processes, effective and competitive data management and the strengthening of green financing activity. We describe the forms of the achievement of this goal as follows:

A. Sustainability on the level of the banking sector - compared with foreign participants, the Hungarian banking sector ought to be managed in a competition-neutral manner.

1) Electronic financial transactions ought to be regulated in a sector-neutral way, and the rules of transaction duty ought to be fine-tuned in order to drive clients towards more eco-friendly channels.

In our opinion, in Hungary, the "same activity - same regulation" principle is still not fully complied with. The main competitive disadvantage for domestic banks compared with foreign FinTech service providers and neobanks is the financial transaction duty, in particular the financial transaction duty on the electronic transfers conducted by retail clients. As foreign FinTech service providers and neobanks ${ }^{18}$ operate in a more relaxed

17 Recommendation No. 5/2021. (IV.15.) of the National Bank of Hungary on risks arising from climate change, environmental risks and the consideration of environmental sustainability in the activities of credit institutions, https://www.mnb.hu/letoltes/5-2021-zold-ajanlas-2.pdf

18 Neobanks (internet-only banks) are financial institutions which provide partial or comprehensive banking services. At the same time, they do not have a network of bank branches in the physical 
legislative environment, they are not obliged to pay transaction duty. Consequently, the significant proportion of domestic transfers may be moved abroad. This trend is risky in many respects. On the one hand, a part of domestic payments may get out of the scope of the supervisory control, on the other hand, in the case of deposit misuse, retail clients may suffer significant damage due to possible loss/theft of data or limited deposit protection. Finally, compared with traditional banks, FinTech service providers put less emphasis on the implementation of rules on the prevention of money laundering and terrorist financing, thus enabling the hiding of illegal income. Regulation inequalities may result in national security risks and risks on the client-side. Moreover, the moving of transactions conducted by retail clients abroad is a process that is very difficult to reverse.

It is a competitive disadvantage for domestic banks that the current taxation environment does not support the realisation of package pricing, therefore Hungarian banks are not able to compete with the offers of neobanks in terms of transfer and card transactions. Prior to the introduction of transaction duty, the most popular account packages typically existed on the basis of package pricing. Account holders conducted a considerable part of their electronic transactions free of charge within these packages. In 2012, this practice could not be upheld anymore, as the transaction duty as well as the two free cash withdrawals meant a cost disadvantage of HUF 900/month/client for domestic banks, while a competitive advantage of HUF 1000o/year foreign FinTech service providers, which were not obliged to pay transaction duty.

Having regard to the arguments above, the Hungarian Banking Association suggested the general phasing-out of transaction duty. If the tax type is not phased out in the short run, we recommend the fine-tuning of the regulation as a favourable step towards competition-neutral regulation. In our view, in addition to its favourable effects on the cash flow, the restructuring of the duty on transactions conducted by retail clients could play a significant role in decreasing the high cash demand of the Hungarian economy, as well. In the first place, it would contribute to the development of the population's cash usage habits, the whitening of the economy. It would facilitate the fight against money laundering, and make tax avoidance more difficult. Based on the estimates quoted above, the social cost of cash usage could be HUF 400-500 billion a year. It is in the interest of 
the national economy to reduce this amount. The spread of electronic payment methods could play a key role in this process.

Considering the aspects highlighted above, supposing the maintenance of the transaction duty, the fine-tuning of the regulation of the duty on transactions conducted by retail clients should be carried out as follows:

- We suggest that the obligation to pay duty on non-cash-related (e.g. transfer, collection) electronic transactions should be repealed (based on our estimates, its budgetary impact would be around HUF -11 billion) and the obligation to pay duty on card purchases conducted by retail clients be phased out, as well (based on our estimates, its budgetary impact would be around HUF - 3 billion).

- At the same time, we recommend that the transaction duty on cash payment from a payment account exceeding the amount of two cash withdrawals in accordance with Section 36/A of Act LXXXV of 2009, as well as on cash payment by non-cash means of payment should be raised from $0.6 \%$ to $1.0 \%$. Based on our estimates, such steps would generate extra revenue of HUF 14 billion for the budget.

As we see, the restructuring proposal described above would have significant advantages for each participant. The revenues of the central budget from transaction duties would not decrease compared to the previous period. Moreover, the amendment would mean extra tax revenues for the budget due to the whitening of the economy. The amendment would also be advantageous for the population, as the charges of transfer transactions could return to the level of the period prior to the introduction of the transaction duty due to the amendment and the competition (this level was near zero in the case of electronic transactions). In our view, the monthly cash amount of HUF 150000 covers everyday expenses (e.g. shopping in the market, payments to school, etc.). Banks would have the opportunity to apply package pricing, as the marginal cost of transfers would be nearly zero.

2) Furthermore, it would be practical to support the slowing down of the growth rate of cash holdings of retail clients.

Cash-free payment solutions may significantly improve the transparency and competitiveness of certain industries and, increasingly, those of the agricultural sector, where still cash transactions are dominant. Some of the proposals made by the Digitalisation Working Group of the Hungarian Banking Association in 2019 have been implemented; however, certain elements are still actual today. Such examples are the introduction of the cash usage limit of HUF 500000 between economic operators as well as 
the amendment to the regulation of financial transaction duty described in the previous point.

The effect of high cash holdings on sustainability is also important in terms of the environmental footprint. Here, we should write about the production, transportation and scrapping of cash. Each of these activities has significant effect on the environment, not to mention the extremely high costs.

\section{B. It is necessary to strengthen the sustainability of financing, address en- vironmental, social and governance (ESG in short) aspects and promote green financing.}

In the preamble of its 2010 directive on the energy efficiency of buildings, the European Union stipulates that the reason for adopting the law was that $40 \%$ of the total energy consumption of the European Union is related to buildings. In its strategy on the modernisation of buildings published in 2020, the European Commission presents similar data: on the whole, buildings are responsible for $40 \%$ of the total energy consumption of the EU and for $36 \%$ of greenhouse gas emissions from energy. It is no coincidence: the building stock is old ( $85 \%$ of all buildings were built before 2001), outdated and does not comply with modern energy efficiency criteria. Currently, outdated real properties constitute two-thirds of the real property portfolio, while only $1 \%$ of them undergo energetic modernisation a year, which is not nearly enough for the renovation of the building stock to achieve climate goals. According to the document, "the EU should urgently focus on how buildings can be made more energy efficient, emit less $\mathrm{CO}_{2}$ and be more sustainable throughout their entire life cycle." The modernisation of the building stock may significantly contribute to the success of initiatives against climate change.

For geographical and historical reasons, the parameters of the energy efficiency of Hungarian residential buildings are unfavourable, as well. The Hungarian residential building stock is old and outdated in terms of energy efficiency. The number of apartments to be renovated is quite high, as nearly $80 \%$ of domestic residential properties were built prior to 1990. Due to the unfavourable energy efficiency of old buildings, the energy consumption of buildings built prior to 1959 is more than three times higher than that of new residential buildings. The energy demand of their heating is more than four times higher. Buildings built between 1976 and 1989 have more favourable parameters, however, their energy consumption is still more than twice as high as that of new residential buildings. The energy demand of their heating is more than two and a half times higher.

The data above are supported by the statistics on the energy performance certificate of residential buildings. In Hungary, it has been compulsory to prepare 
an energy performance certificate when using, selling and letting real properties since 2012. The certificate provides detailed information on the energy consumption of the real property. Since 1 January 2016, a stricter energy efficiency rating scale has been in effects. Buildings are divided into 12 classes. Merely 2.1\% of the certificates issues between 2016 and 2019 met the energy demand criteria of nearly zero (in the upper four categories), $19.5 \%$ were rated as modern (CC) and the remaining $78.4 \%$ received worse ratings.

Both the credit institutions and the National Bank of Hungary, which prepared different incentive programmes, recognised that the first area where any change could be achieved and any contribution to the energetic modernisation of the domestic residential property stock and the support of sustainability goals could be achieved was mortgage lending. In order to achieve this, the legislator's support is essential: first, the legislator should fine-tune the legislative environment, provide access to energetic data and provide state programmes supporting energetic modernisation.

3) We recommend the support of the energetic modernisation of the domestic residential property stock and the revision of the laws which make this process more difficult.

a) Considering the characteristics of the domestic property stock, we believe that one of the most important sustainability elements is the support of the energetic modernisation of residential properties. However, at the moment, the incentive programmes of the state and the central bank (the Green Home Programme and the related subsidised homebuilding loan) support either the purchase and construction of new energy efficient real properties, or their general modernisation. In the light of the above, we recommend the development of subsidised constructions and programmes through which the rate of modernisation of the real properties can be accelerated. Such incentives could be subsidies provided to clients, tax advantages or, in the case of refinancing, interest-rate subsidy solutions or adding elements supporting energetic modernisation to existing forms of subsidy (Village Family Housing Subsidy, subsidised home improvement loan). As far as the aforementioned incentives are concerned, it is worth taking into account the objectives of e.g. the EU Bauhaus Project, which seeks to alloy planning, sustainability, accessibility, affordability and investments ${ }^{19}$.

19 EC (2021): New European Bauhaus: Commission launches design phase, https://ec.europa.eu/ commission/presscorner/detail/en/ip_21_111. 
b) Regarding the achievement of sustainability goals, in addition to new energy efficient real properties, the energetic modernisation of the existing real property stock may play a key role, as well. This activity is supported by both international (the New Bauhaus initiative) and national (the National Bank of Hungary's Green Capital Allowance Programme); however, there has not been any breakthrough in this field yet. In our opinion, one of the basic criteria of the bank funding of modernisation works is that the pre- and post-modernisation energetic data of the real property should be available to clients as well as to the financing financial institutions in a way that does not lead to an increase in the ancillary costs of lending. As international examples $^{20}$ also show, a loan can be considered as green if the real property's energy efficiency is improved by $30 \%$. However, most of the buildings concerned do not have an energy performance certificate, therefore the measurement of modernisation would require the preparation of two energy performance certificates or the assessment of the completed works by an independent expert. The aforementioned two solutions would considerably increase the costs and administrative burdens of the lending process. At the same time, the goal is to encourage real property renovations by providing available loans with more favourable pricing. In such cases, the problem could be solved by providing simplified energy performance certificates of the real properties to the clients free of charge, and by centrally determining the percentage by which energy efficiency could be improved by executing the individual renovation works.

c) At this stage, legal rules related to the modernisation of condominiums should be revised, as well. In its 2020 Housing Market Report ${ }^{21}$, as part of the survey on the technical condition of domestic condominiums, the National Bank of Hungary presented renovations planned and completed earlier, as well as the necessary sources of funding and obstacles to renovations. $66 \%$ of the respondents in the survey claimed that the lack of state resources, $51 \%$ said that the low amount of the savings of condominiums, while $25 \%$ answered that the lack of agreement

20 Association of German Mortgage Banks (vdp) - Minimum standards for use of the wordmarks "Green Pfandbrief" / "Grüner Pfandbrief" (for Mortgage Pfandbriefe), https://www.pfandbrief. de/site/dam/jcr:4b2oof2e-8dd7-49d5-ab84-d89144d37164/2019-o8_vdp_mindeststandards_ GPB_EN.pdf.

21 https://www.mnb.hu/kiadvanyok/jelentesek/lakaspiaci-jelentes/lakaspiaci-jelentes-2020november. 
between the owners, which was required for the investment, was the main obstacle to renovation.

As far as reconstruction and modernisation works beyond the scope of normal management are concerned, currently, the Condominium $\mathrm{Act}^{22}$ prescribes the unanimous decision of co-owners. Expenses related to works which do not belong to the category of conservation and maintenance (operation, maintenance and renovation) are beyond the scope of normal management. Based on the deed of foundation, such works include the extension of the building or part of the building which is in co-ownership or the construction of a new building, a part of building or building installations which get into co-ownership.

Based on common judicial practice, when deciding whether an expense is beyond the scope of normal management, not only the amount of the cost, but also the goal of the investment as well as the planned or achieved result has to be examined and assessed.

The Curia's Summarising Opinion ${ }^{23}$ No. 2016.El.II.JGY.P.1. on the activity of the case law analysing group, which was established to examine certain procedural and pecuniary issues of legal disputes of condominiums includes a list as guidance on which expenses are within the scope of normal management and which are beyond it. For example, in the case of the panel building renovation programme, external insulation and the replacement of fenestrations are not beyond the scope of normal management, therefore the decision requires only simple majority, while the installation of solar collectors exceeds the scope of normal management, therefore unanimous vote of the co-owners is needed.

According to judicial practice, expenses related to both the upgrading of heating systems and the involvement of renewable energy sources are beyond the scope of normal management, therefore it would be practical to include energy-saving renovation works as expenses within the scope of normal management in the Condominium Act, facilitating the situation of condominiums and co-owners that seek to improve the energy efficiency of the buildings.

22 Act CXXXIII of 2003 on Condominiums.

23 https://kuria-birosag.hu/sites/default/files/joggyak/vegleges_es_javitott_tarsashazi_joggyak._ osszefoglalo.pdf. 
4) The data about the energy efficiency of residential properties and the state databases supporting corporate green financing should be openly available to the general public.

a) Based on international practice, regarding energy efficiency, buildings belonging to the best $15 \%$ of the real property portfolio of a given country can usually be considered as green. As we explained above, a significant part of the best $15 \%$ of the domestic real property stock consists of a currently undefinable group of buildings with "CC" energetic rating. Within the category $\mathrm{CC}$, we could decide which real properties belong to the best $15 \%$ and which real properties are outside this limit only on the basis of the aggregated energetic data of the individual real properties $\left(\mathrm{kWh} / \mathrm{m}^{2} \mathrm{a}\right)$. Currently, the aggregated energetic data $(\mathrm{kWh} /$ $\mathrm{m}^{2} \mathrm{a}$ ) can be found only in energy performance certificates, while the category of energy efficiency rating is available to the general public on a website operated by the Lechner Knowledge Centre ${ }^{24}$. With regard to the fact that concerning existing collaterals, energy performance certificates are not available to institutions, data shortage related to energy efficiency classification and the aggregated energetic data is a serious difficulty regarding green mortgage lending and the issue of green covered bonds at the moment.

An effective solution to the problem described above would be if

- mortgage banks were given the energy performance certificate data related to collaterals in their portfolio - in this way, the initial population of data could be achieved and

- the aggregated energetic data of the real properties $\left(\mathrm{kWh} / \mathrm{m}^{2} \mathrm{a}\right)$ were added to the publicly available energy efficiency data of the real properties on the website managed by the Lechner Knowledge Centre.

b) One of the most important elements of the criteria of corporate green financing is the taxonomy regulation of the European Union ${ }^{25}$. The taxonomy regulation details the quantitative and qualitative assessment criteria based on which a given activity can be considered as environmentally sustainable and complies with the requirements of green fi-

24 https://www.e-epites.hu/e-tanusitas.

253 Regulation (EU) 2020/852 of the European Parliament and of the Council of 18 June 2020 on the establishment of a framework to facilitate sustainable investment and amending Regulation (EU) $2019 / 2088$. 
nancing. An economic activity can be qualified as green if it can be proven that the economic activity concerned significantly contributes to the achievement of at least one of the environmental objectives ('substantial contribution'), while not causing any substantial damage to other environmental objectives ('substantial damage') (subsection [54] of the preamble of the regulation $)^{26}$. An important criterion for the success and spread of green lending is the reliability and comparability of data. In addition, the collection of data should not be a disproportionate administrative burden on those participating in financing. In the light of the above, we believe that the data available in state databases are the most suitable for proving compliance with sustainability criteria.

In view of the foregoing, we suggest that the legislator should provide access for banks to the databases which can play a role in supporting green financing as well as in determining and proving the sustainability of the renewable energy and infrastructural investments to be implemented. In our view, such databases include primarily the detailed license database of Hungarian Energy and Public Utility Regulatory Authority, the data in the National Environmental Information System (OKIR) and the data collected and forwarded to the ETS (Emission Trading System) by the department in charge of $\mathrm{CO}_{2}$ emission trading of the National Climate Protection Authority.

5) In order to facilitate the exploitation of the agricultural aid of HUF 4,265 billion in the funding period between 2021 and 2027 , we suggest the launch of a financing sub-programme.

Those who are involved in agricultural financing welcomed the latest governmental measures related to the Rural Development Programme with unanimous enthusiasm. Based on these measures, between 2021 and 2027, $80 \%$ national co-financing is to be provided to the budget of the European Agricultural Fund for Rural Development of the Common Agricultural Policy (CAP). As a result, the government intends to spend EU and national resources of HUF 4,265 billion on rural development by 2027 . The decision and the resources create a huge opportunity for the agricultural sector. According to the plans, resources should serve several purposes: the development of the infrastructure and the economy, the conservation

26 Katalin Dobránszky-Bartus - Krenchel Jens Valdemar (2020): The EU's taxonomy regulation: the first "green" dictionary of investment activities), Economy and Finance, 7(4), 386-411. 
of the countryside, the recovery of local economy and the establishment of a powerful and competitive modern agricultural sector.

By phasing out the Go For It Growth Loan Programme, the circle of programmes available for financing of investments related to the subsidies of the Rural Development Programme has shrunk considerably. In the case of many facilities, the funding of primarily agricultural and previously subsidised projects is a reason for disqualification. In addition, in the framework of the Rural Development Programme, tenders are usually approved of with maximum aid intensity, which also limits access to other subsidised facilities.

Currently, the Hungarian Development Bank still does not provide refinancing to commercial banks in the field of agriculture, while, in the case of the available facilities of EXIM, the EXIM Competitiveness-Promoting Loan Programme is not available for agricultural clients. Concerning the export-stimulating products of EXIM, the subsidy cannot be linked to the facility, therefore the funding of the investments of the Rural Development Programme is not possible within the framework of this programme, either. As far as EXIM programmes based on temporary supports schemes available until the end of 2021, the maximum grant equivalent also refers to a strict limit. The already unavailable EXIM Mitigating Programme was not suitable for the funding of these projects due to its maturity of 6 years. In the case of the EXIM Turn Programme, the maximum loan amount of HUF 3.5 billion could be suitable for financing the investments of the Rural Development Programme, however, grant equivalents are restrictive, the maximum grant equivalent of EUR 225 thousand, calculated with an interest-rate subsidy of $1.5 \%$ for clients with good rating allows a maximum loan amount of HUF 1 billion, for clients with satisfactory rating (with an interest-rate subsidy of 3.3\%), the highest amount of the loan could be only HUF 500 million. Moreover, due to the cumulation of aid, this grant equivalent also has to fit into the room for decrease in aid intensity of the Rural Development Programme. The maturity of 10 years results in demanding repayment, as well.

With its fix and low interest rates, the Agricultural Széchenyi Restart Investment Loan, which is considered to be the successor of the Go For It Growth Loan Programme, could be an optimal solution, but similarly to the EXIM facility, due to the maturity of 10 years and even higher grant equivalent (an interest-rate subsidy of $7 \%$, a budgetary fee subsidy of $1 \%$ and an administration fee subsidy of $0.5 \%$, the title 3.1 aid limit of EUR 225 thousand enables a loan amount of only about HUF 200 million. 
Based on the above, we may conclude that none of the available programmes with preferential fixed-interest rates in the market provides an optimal solution to the financing of the investments related to the subsidies of the Rural Development Programme. Due to the interest rates rising according to expectations, floating rates carry a serious risk, which some clients, based on their previous experience, do not want to take. Due to a significant increase in costs, the participants delay the start of the investments. As far as tenders which are just being published, facilities offered within the framework of temporary support schemes are available only until the end of 2021, therefore they do not provide an alternative financing option.

The achievement of the goals of the Rural Development Programme requires a facility with a favourable fixed interest rate and long-term maturity, and definitely without a grant equivalent. Financing problems could be solved by a loan programme that could be easily available with more limited purpose than the previous programme for investment purposes, with a maturity of 20 years, with a maximum credit amount of HUF 3 billion, a fixed interest rate of $2.5 \%$, without grant equivalent and preferential deposit. The loan program would be sector-neutral and available to all industries. The suggested programme would be in line with the Government Restart Programme and ensure the gradual phasing-out of the financing taking place in the framework of the Growth Loan Program and has become an integral part of the whole lending practice over the years.

6) We suggest the development of a long-term green criteria system applying to all sectors.

In her speech given on 11 July 2021, ECB President Christine Lagarde emphasised that the supply of green data should be as appropriate as possi$b^{27}$. The suggestion applies not only to Hungary, but also to Europe and the whole world: according to a study prepared by the European Commission in $2020,{ }^{28}$ currently, there are nearly 150 green and ESG certification and rating bodies, all of which apply different methodologies, making the comparability of various rating and rankings more difficult. A reliable, widely-accepted certificate would make green financing easier (currently, as if there existed several dozens of different energy performance certifica-

27 Christine Lagarde (2021): Climate change and central banks - analysing, advising and acting. Speech by Ms Christine Lagarde, President of the European Central Bank, at the International Climate Change Conference, Venice, 11 July 2021. https://www.bis.org/review/r210712b.htm.

28 Study on sustainability-related ratings, data and research, https://op.europa.eu/hu/publicationdetail/-/publication/d7d85036-509c-11eb-b59f-o1aa75ed71a1. 
tion methodologies for buildings). It was also suggested that a system of minimum requirements should be set up. Market participants could outperform these requirements due to appropriate incentives, which would drive them towards conscious and sustainable activity. The introduction of a certified green bank "brand" in the financial sector could be an opportunity for and a standard of this, allowing clients to follow the environmental effects of financial services and products. Or even such an indicator could be introduced that would assess the sustainability of the activity of individual banks. The key performance indicators could be based on the assessment of considerations and methods which play a role in the lending and investment activity and operation of the given bank and serve sustainability. The rating could also provide an opportunity for investors to see the various sustainability features (ethical/green/ESG etc.) of investment products clearly. The names of an increasing number of products already contain such a buzzword, but these are usually self-styled labels. Today, still nothing prohibits the so-called greenwashing, i.e. gross exaggeration of environmental advantages.

The partial implementation of this concept has also started in the European Union. The aim of the draft regulation ${ }^{29}$ on European green covered bonds is to establish a common framework for interpretation based on the taxonomy regulation, as well as to regulate the registration and supervision of external rating companies. When finalising the regulation, it would be important in terms of legal certainty and the protection of investors that the green bonds issued earlier should preserve their green character.

C. Sustainability for clients: More effective, more cost-efficient and ecofriendly administration provided to clients is key to sustainability.

7) We suggest that indirect costs related to lending should be decreased.

a) In the case of businesses, the notarial fees and practice applied until 2018 should be reintroduced: The new regulation on notarial fees raised the fee cap from HUF 200 million to HUF 1 billion, thus multiplying the borrowing costs of enterprises. In order to keep notarial fees reasonable, the fee cap should be set at HUF 200 million again.

b) It might be appropriate to cancel the reading out of notarial deeds in the case of legal entities. The institution of notarial reading was established by the imperial chart of 1858 , having regard to the typi-

29 https://ec.europa.eu/info/business-economy-euro/banking-and-finance/sustainable-finance/ european-green-bond-standard_en 
cally illiterate parties ${ }^{30}$. At the time, its existence was justified. However, nowadays, it makes the process of entering into transactions more difficult, therefore, professional economic operators (representatives of enterprises) should have the opportunity to request the cancellation of reading out unless they are acting through a legal representative.

c) The use of notarial samples should be extended. In the case of loans subsidised by the state, the legislator created a unilateral commitment statement sample. If this sample is used, the notarial fee shall not exceed HUF 19,500. The favourable rule still does not apply to most mortgage loans. In such cases, the parties face extremely high fees, which may not appeal to clients, considering the current average wage in Hungary. In view of the above, in addition to loans subsidised by the state, clients should have the option to use a sample in connection with consumer mortgage loans, with a maximum fee of HUF 35,000 .

d) It might be appropriate to make sure that the new land registry procedure does not increase borrowing costs. The automated decisionmaking procedure introduced by the land registry act could make land registration procedures faster and cheaper. At the same time, the new abolishes the possibility to establish mortgage based on a private document affixed with the authorised signature of the credit institution, as well /Section 32 (5) of Act CXLI of 1997 on Land Registration/. Due to the involvement of attorneys, bar association legal counsels or notaries, the procedure to change the current process will be more expensive.

e) In cases where the notarial deed also contains a loan or guarantee contract or the debtor's unilateral commitment statement, the notary should initiate the registration of the mortgage in the framework of the main proceedings, and the notarial fee should include the notarial service related to the registration of the mortgage.

f) We suggest the establishment of a new registration system for the registration of receivables.

g) In accordance with the government's digitalisation efforts, it should be worth examining how a digital registration system which would ensure the registration and the enforcement of claims in a more timeand cost-efficient manner than the current one could be developed. The goal would be supported by the establishment of a system that is similar to a credit guarantee registry and would function as a registry

30 GÁвоR Rokolya (2013): A közjegyzői intézmény fejlődése a polgári korban. Budapest, Gondolat Kiadó. 
of loan and guarantee contracts related to the credit relationship as well as that of commitment statements. Compared with the current paper-dominated administration, it would mean the establishment of a completely new system. Where applicable, this new registry system can be developed even without the involvement of notaries, however, the IT system of the Hungarian National Chamber of Civil Law Notaries could provide an appropriate basis for the establishment of such a platform.

8) The fuller exploitation of the e-administration law should also be considered (AVDH, storage space usage).

In the framework of the government's digitalisation initiatives, several developments have been realised to provide help to millions of citizens with their administrative duties. In our opinion, the instruments of the E-Administration Act may make banking, which is similar to public services in character, more effective. For example, such an instrument could be the provision of the use of storage space to support communication with clients and the integration of Identification-Based Document Authentication (AVDH) into banking processes. As far as the latter is concerned, it would be practical to recognise AVDH as a method of procuration and allow multiple persons to authenticate a given document in the framework of AVDH (currently, the system does not allow more than one authentication).

The proposal is made especially actual by Government Decree 1170/2020. (IV.21.) pursuant to which electronic administration services provided by the National Infocommunications Service Company Ltd. (NISZ) shall be available to Garantiqa Loan Guarantee Plc. The aforementioned example indicates that the legislator has made a step towards providing electronic administrative services to financial institutions, as well.

\section{9) We suggest the provision of general access to positive CCIS data.}

Following the German example, the introduction of the extended and generally accessible positive credit register would support the restart of the economy by accelerating the borrowing procedure, improving the international competitiveness of Hungary. In banking operation, it could be highly compatible with green lending objectives, therefore, we believe that the Act on the Central Credit Information System should be amended in an appropriate way. 
10) We suggest the introduction of a "green month" focusing on the topic of sustainability.

By the introduction of a symbolic "green month", consumer education can be strengthened and the transition to sustainability banking and banking that serves general sustainability in the best possible way can be facilitated. In the thematic month, the banking sector would encourage clients to change to green products by offering targeted programmes. In the case of the clients who are susceptible to sustainability, additional sustainable financial products and services could be provided. In addition, joint financial education programmes with the National Bank of Hungary, the Ministry of Finance and the European Money Markets Institute, EMMI, can be complemented with the topic of sustainability.

\section{SUMMARY}

As our study shows, the banking sector plays a key role in the achievement of sustainability goals. Similarly to all sectors of critical importance, it can set an example for different generations and social groups. The banking sector is also committed to representing values related to sustainability, in the hope of being able to contribute to the fullest possible achievement of global environmental goals. Otherwise, our attention has been drawn to the topic by the increasing number of scientific works written since the beginning of the third millennium, and, most importantly the volume and depth of serious EU-level initiatives. If we want to follow or perhaps even complement the evolved trend, the principles of sustainable banking should be laid down in Hungary, as well. The Hungarian Banking Association, which represents the banks operating in Hungary, believes that the following measures have the highest potential regarding sustainability: shortening current banking processes, reducing the data volume used in administrations and the time on it. Along the aforementioned principles, we can summarise in 10 points those proposals by the consideration and implementation of which the Hungarian banking system could definitely strengthen its own sustainability and could significantly contribute to complex sustainability, as well. 


\section{REFERENCES}

Aracil, E. - Nájera-Sanchez, J. J. - Forcadell, F. J. (2021): Sustainable banking: A literature review and integrative framework. Finance Research Letters, https://doi.org/10.1016/j. frl.2021.101932.

BeCsei, A. - Bógyi, A. - CsÁnyi, P. - Kovács, L. (2019): The Bank of the Future, the Future of Banks Digitalization proposals by the Hungarian Banking Association. Economy and Finance, 6(3), 311-322. https://www.bankszovetseg.hu/Public/gep/2019/ENG/311-322\%20E\%2oBecsBodCsaKo. pdf.

Birindelli, G. - Ferretti, P. - Intonti, M. - Iannuzzi, A. P. (2015): On the drivers of corporate social responsibility in banks: evidence from an ethical rating model. Journal of Management \& Governance, 19(2), 303-340. https://doi.org/10.1007/s10997-013-9262-9.

Bouma, J. J. - Jeucken, M. - Klinkers, L. (eds.) (2017): Sustainable banking: The greening of finance. London: Routledge, https://doi.org/10.4324/9781351282406.

EC (2021a): A European Great Deal. https://ec.europa.eu/info/strategy/priorities-2019-2024/european-green-deal_en (downloaded at 03.06.2021).

EC (2021b): Sustainable Finance. https://ec.europa.eu/info/business-economy-euro/banking-andfinance/sustainable-finance_en (downloaded at 01.06.2021).

EC (2021c): New European Bauhaus: Commission launches design phase: https://ec.europa.eu/commission/presscorner/detail/en/ip_21_111 (downloaded at 01.06.2021).

Forcadell, F. J. - Aracil, E. - Úbeda, F. (2020): The Impact of Corporate Sustainability and Digitalization on International Banks' Performance. Global Policy, 11, 18-27. https://doi. org/10.1111/1758-5899.12761.

SCHriber, A. - Koppes, S. (2021): Climate risk is financial risk - For banks it's a board-level issue. KPMG, 7 April, https://home.kpmg/xx/en/home/insights/2021/04/banks-climate-changereporting.html (downloaded at 07.10.2021).

YIP, A. W. H. - Bocken, N. M. P. (2018): Sustainable business model archetypes for the banking industry. Journal of Cleaner Production, 174, 150-169, https://doi.org/10.1016/j.jclepro.2017.10.19o.

NBH (2021): Föld- és készpénzkímélő fizetési módok [Land- and cash-effective payment methods]. National Bank of Hungary, https://www.mnb.hu/fogyasztovedelem/csaladi-zold-penzugyek/ zold-penzugyi-megoldasok/zold-penzugyi-megoldasok-a-gyakorlatban/fold-es-keszpenzkimelo-fizetesi-modok (downloaded at 20.07.2021). 